\title{
Inequality Publication of Local Communities in Local Paper
}

\author{
Sunarto Sunarto*, Dwi Purbaningrum, Adi Nugroho, Heni Indrayani and Anna Puji Lestari \\ Information System Department, Universitas Diponegoro, Tembalang - Indonesia
}

\begin{abstract}
The development of new technology such as internet and social media makes the future of the paper industries are getting worse. Local media does not immune from the phenomena. Serving to its communities is one of the strategy to be survive. It is done by several papers in Java Island. One of them is Suara Merdeka daily. How did this paper actualize its strategy on its framing content? Describing the frame of the information which was used to serve its communities was the main objective of this research. A framing theory and framing analysis in constructive paradigm was used to answer the problem. The content of Suara Merdeka daily was chosen purposively to get the evidence. There were some rubrics that contained the service to communities namely "Fokus Jateng”, "Liputan Khusus", “Telisik”, "Spektrum”, "Her Spirit”, “Jalan-jalan”, "Layar”, "Trending Topic", and "Hello Kampus". The result showed more information framing on news than another framing. Besides, a certain education institution was published more than others. There was an unequal treatment to communities to be published in the paper. It is suggested, in the future, the paper should give the same treatment to its communities.
\end{abstract}

Keywords: Local Paper; Community Service; Framing Analysis

\section{Introduction}

Mainstream mass media such as newspapers in the world tended to decline based on their income and readership. People changed their habit in consuming media. Mainstream mass media closed to adult audience, meanwhile the youth audience were more influenced by internet and social media. It was hoped the youth might keep the existence of mainstream mass media in the middle of technology development recently. It was asserted by "One Young World 2016" in Ottawa, Canada several times ago[1].

Digital development attached some global, national and local newspapers. Boston Globe Daily in Boston, US, Sinar Harapan Daily, Bola Daily, Jakarta Globe Daily in Jakarta, Kartika Daily in Semarang were closed that be caused by the technology[2]. There were some local papers gave an assignment to their reporters to get some advertising from their sources. The reporter did multitasking[3].

Haryanto ${ }^{4}$ showed that the life of newspapers in Indonesia were depended on several factors such as: (1) the development of digital technology, (2) the slow of economic development, (3) the sift of reading habit from print media to online media, (4) the youth generations were not becoming yet to be future reader.
Sunarto and Nugroho showed that there was a prospective future of local paper in Java Island, Indonesia. It was seen by the optimism views of several leaders of local papers when be asked about the future of their papers. Through a service leadership style they believed it might support and develop their papers. They would optimize the development of new technologies to support their papers.

In this leadership style, the leader of local papers gave themselves to their communities as a solution to communities' problems. Their papers become a referential sources, a marketing service, a political and cultural identification to its communities through many rubrications and a special page.

It was coherent with recommendation of World Association Newspaper (WAN) in 2000 to face the development of internet: (1) do not remote from readers communities; (2) developing professional potentialities and deleting beurocracy; (3) keeping reporter's credibility in society; (4) integrating editorial and business, deleting fire wall; (5) creating new readers, women and youth; (6) activating research and development; (7) entering in multimedia, online and offline; (8) giving a performance that make fast readers to consume easily; (9) making a plan, anticipation, and preparation; (10) do not let newspapers to be "a church without spirit", do not leave a vision, intellectual

\footnotetext{
*Corresponding author: sunarto@undip.ac.id
} 
capacity, good intention, fair play, and want to know the communities problems[5].

Based on the background, this research wanted to describe the content of local paper in Semarang, Central Java, Indonesia, namely Suara Merdeka Daily, in giving its service to its community's readers.

\section{Methodology}

This research used a second agenda-setting theory namely a framing theory of mass media[6] in a constructive paradigm[7] to understand of the local media content.

Data was obtained from the content of Suara Merdeka Daily especially on April 2017 edition. Framing analysis method of Gamson and Modigliani[8] was used to describe the content. According to them, the media package presents the keywords and common language that would help identify a particular frame; offers a number of different condensing symbols that suggest the core frame \& positions in shorthand, making it possible to display the package as a whole with a deft metaphor, catchphrases or other symbolic device.

There were 83 articles that be coverage on 9 rubrics on April 2017 as a special page namely: (1) Liputan Khusus (Special Coverage); (2) Fokus Jateng (Central Java Focus); (3) Spektrum (Spectrum); (4) Telisik (Investigate); (5) Trending Topic; (6) Layar (Screen); (7) Hello Kampus (Hello Campus); (8) Her Spirit; (9) Jalan-jalan (Traveling). These rubrics were published routinely every week.

The rubrics were considered as rubrics that served the communities in Central Java since it's appeared relatively routine and served special audience. For instances, Layar and Hello Campus served education communities. Her Spirit served female communities. Jalan-jalan served travelers communities. Trending Topic served photographers communities. Liputan Khusus, Fokus Jateng, Spektrum, and Telisik served special communities since its theme changed dynamically according the actual affairs in society. The fourth last rubrications appeared as features about hot and actual issues in society that needed to investigate or explore intensively and deeply. The summary of the findings of this research might be seen on table below.

Table 1. Summary Research Findings

\begin{tabular}{|l|l|l|l|}
\hline No & Rubrics & $\begin{array}{l}\text { Article } \\
\text { s }\end{array}$ & Core Frame \\
\hline 1 & $\begin{array}{l}\text { Liputan } \\
\text { Khusus }\end{array}$ & 8 & Social control (8) \\
\hline 2 & Fokus Jateng & 10 & Education (10) \\
\hline 3 & Spektrum & 17 & $\begin{array}{l}\text { Social control (7); } \\
\text { Education (1); } \\
\text { Information (9) }\end{array}$ \\
\hline 4 & Telisik & 3 & $\begin{array}{l}\text { Social control (2); } \\
\text { Education (1) }\end{array}$ \\
\hline 5 & $\begin{array}{l}\text { Trending } \\
\text { Topic }\end{array}$ & 2 & Social control (2) \\
\hline
\end{tabular}

\footnotetext{
*Corresponding author: sunarto@undip.ac.id
}

\begin{tabular}{|l|l|l|l|}
\hline 6 & Layar & 19 & Information (19) \\
\hline 7 & Hello Kampus & 12 & $\begin{array}{l}\text { Education (5); } \\
\text { Information (7) }\end{array}$ \\
\hline 8 & Her Spirit & 8 & $\begin{array}{l}\text { Education (7); } \\
\text { Information (1) }\end{array}$ \\
\hline 9 & Jalan-jalan & 4 & Information (4) \\
\hline & Total & $\mathbf{8 3}$ & $\begin{array}{l}\text { Social control (19); } \\
\text { Education (24); } \\
\text { Information (40) }\end{array}$ \\
\hline
\end{tabular}

The core frame of many articles in April 2017 edition were more information framing than social control or education. It meant that many articles just showed something that needed to know by audience about something new related with places, things, achievements, or events. There were no criticism to government or society like as on social control framing or to persuade people to do or to support something or someone on education framing. This research also found that there was a certain education institution published more than others namely Dian Nuswantoro University (Udinus) on Layar. It appeared every week on a special page.

\section{Discussion}

It is interesting to be discussed why there were more information framing on news to communities in local papers in Suara Merdeka than social control, education, or entertainment. As we know, the main duties of mass media in our county are to inform, educate, entertain, and social control (Press Law, 1999). Meanwhile, according to McQuail[9], media has several functions: information, correlation, continuity, entertainment, and mobilization.

Media conducts an information function when providing information about events and conditions in society and the world, indicating relations of power, and facilitating innovation, adaptation and progress. Media is doing a correlation function when explaining, interpreting, and commenting on the meaning of events and information, providing support for established authority and norms, socializing, coordinating separate activities, consensus building, and setting orders of priority and signaling relative status.

Expressing the dominant culture and recognizing subcultures and new cultural developments, and forging and maintaining commonality of values are the function of media on continuity. Its function on entertainment may be seen when media is providing amusement, diversion and the means of relaxation, and reducing social tension. Mobilization of media function may be known through campaigning for societal objectives in the sphere of politics, war, economic development, work, religion and environmental issues. By using media for the environmental issue campaign, it can arise public environmental awareness. Rahim \& Jalaladeen (2016) did research about the usage of media in 
spreading environmental awareness, in conclusion, the participants were used the social media to get news and information as number one, increase their knowledge as number two, raise awareness about science and education as number three, and finally increase environmental awareness as number fourth. Media campaign also can be a social control which can criticize government policy and deliver its input in policy making.

There is no education and social control on McQuail functions of media. The both function implicitly may be seen on the information function, correlation, continuity, and mobilization. However, in another side, McQuail[9] said, there were term "fourth estate" to be labelled on media function. It meant to political power possessed by the press, on a par with the other three "estate" of power in British realm: Lords, Church and Commons. The power of the press arose from its ability to give or withhold publicity and from its informative capacity. In our interpretation, the term "fourth estate" is implying on the social control function when media does to control the elite power on executive, legislative, and judicative bodies. In its extensive meaning, its function may include the power media to control society in the whole.

In an extensive definition, Erving Goffman[10] said, framing refers to schemata of interpretation that enable individuals to locate, perceive, identify and label occurrences or life experiences.

According to Robert Entman[6], to frame is to select some aspects of perceived reality and make them more salient in a communicating text, in such a way as to promote a particular problem definition, causal interpretation, moral evaluation, and/or treatment recommendation for the item described.

Meanwhile, according to D'Angelo and Kuypers[11], much framing research focuses on ways that politician, issue advocates, and stakeholders use journalists and other news professionals to communicate their preferred meanings of events and issues. The essence of framing: sources frame topics to make information interesting and palatable to journalists, whom they need to communicate information to wider publics, and journalists cannot not frame topics because they need sources' frames to make news, inevitably adding or even superimposing their own frames in the process.

According to Tewksbury and Scheufele[12], regardless of its theoretical underpinnings, framing research argues that news frames function to suggest how audiences can interpret an issue or event. In fact, news frames can exert a relatively substantial influence on citizens' beliefs, attitudes, and behaviors. Therefore, it is not surprising that they appear to be related to other consequential processes in news consumption and processing.

The consequential processes of news framing may create the benefit of an economic, social, cultural or political support from communities. For media in common, the benefit is needed to support its life, especially economic benefit. It is understood if a local media publishes a certain institution more than others when they make some joint cooperation in certain circumstances. Both parties get benefit in supporting of their economic needs and others such as social, cultural or political. News framing may fulfill the needs.

According to Volkmer[13], not surprising then, is that framing theory has become important for a variety of sectors within today's transnational media society. Knowledge about framing theory is crucial for the planning of media campaign in advertising, public relations, and political sectors. It is meant that news framing becomes something strategic to media institution to get its goals related with its economic, social, cultural, and political interests.

\section{Conclusion}

Inequality publication communities on local paper it seem something that may not be run away since it is related with certain benefit for both media or the institution on society that need the publication on media. Media framing becomes something important since its capacity to make an institution, an individual or something in society more salient than others on media. The consequential processes may get some benefit economically, socially, culturally, or politically for the parties which involved.

Considering the effect of media framing, it is necessary to media institution to give a fair opportunity to all communities to be served through media publication. If the communities feel to be supported in the next processes they will support the media institution economically, socially, culturally, and politically.

\section{References}

1. T. A. Kristanto, Kaum Muda Diharapkan Kembangkan Media Massa, Kompas, 13 (2016).

2. S. Sunarto and A. Nugroho, Esensi Pengalaman Kepemimpinan Manajemen Media Lokal di Pulau Jawa, Research Report, Semarang: DIPA FISIP Undip: 1-188 (2016).

3. S. Sunarto, Esensi Pengalaman Profesional Wartawan Media Lokal, Research Report, Semarang: DIPA FISIP Undip: 1-100 (2015).

4. I. Haryanto, Senja Kala Koran dan Jurnalisme Kita, Kompas, 7 (2016).

5. St. Sularto, Syukur Tiada Akhir, Kompas, (2011).

6. S. D. Reese, Prologue- Framing Public Life: A Bridging Model for Media Research, Framing Public Life: Perspectives on Media and Our Understanding of the Social World, ed. Stephen D. Reese et al., 7-32 (2001).

7. Y. S. Lincoln \& E. G. Guba, Paradigmatic Controversies, Contradictions, and Emerging

$\overline{{ }^{*} \text { Corresponding author: sunarto@undip.ac.id }}$ 
Confluences, Handbook of Qualitative Research (2nd./3rd ed), ed. Norman K. Denzin and Yvonna S. Lincoln, 163-187/191-216 (2000; 2005).

8. T. Jr., James W, The Empirical Approach to the Study of Media Framing, Framing Public Life: Perspectives on Media and Our Understanding of the Social World, ed. Stephen D. Reese et al., 95106 (2001).

9. D. McQuail, McQuail's Mass Communication Theory (4 ${ }^{\text {th }}$ ed.), $168-170$ (2005).

10. E. Goffman, Frame Analysis: An Essay on the Organization of Experience, (1974).

11. P. D'Angelo \& J.A. Kuypers, Introduction: Doing News Framing Analysis, Doing News Framing Analysis: Empirical and Theoretical Perspectives, 1-14 (2010).
12. Tewksbury, David and D. A. Scheufele, News Framing Theory and Research, Media Effects: Advances in Theory and Research ( $3^{\text {rd }}$ edition), ed. Jennings Bryant and Mary Beth Oliver, 17-33 (2009).

13. I. Volkmer, Framing Theory, Encyclopedia of Communication Theory 1, ed. Sephen W. 407-409 (2009).

14. Undang-undang Republik Indonesia Nomor 40 tahun 1999 tentang Pers

15. M. Rahim \& J. Jalaladeen, The Role of Social Media on Environmental Awareness of Undergraduate Students in University of Sulaimani in Iraq, (2016) , ISSN: $2414-3383$.

\footnotetext{
*Corresponding author: sunarto@undip.ac.id
} 